\title{
Editorial
}

\section{A new layer of complication}

\section{J. David B. Oliver, Coopers \& Lybrand Deloitte, London}

As Member States of the European Community move towards implementation in their domestic law of the provisions of the dividends and mergers Directives one can begin to see a new layer of traps for the unwary emerging. Take the dividends directive for example. The simple message that there is to be no withholding tax on dividends from subsidiary companies to parent companies becomes complicated by the now well observed limitation that the directive only applies to dividends on direct holdings between the parent and subsidiary. Even where there is a direct holding however the Directive itself may be limited in its effect because of two derogations which are permitted. The first derogation (in Article 1) provides that the Directive 'shall not preclude the application of domestic or agreement based provisions required for the prevention of fraud or abuse.' The second (contained in Article 3) gives Member States the option of not applying the Directive to companies of that Member State which 'do not maintain for an uninterrupted period of at least two years holdings qualifying them as parent companies or to those of their companies in which a company of another member state does not maintain such a holding for an uninterrupted period of at least two years.'

Taking the second limitation first, it can be applied either to the qualification for the exemption or credit relief, the first part of the provision, or to the exemption from withholding tax on dividends, the second part of the provision, or both. It is most interesting that the Netherlands in its initial proposals in relation to the withholding tax has chosen to take advantage of the derogation and to require that a holding must have been held for at least two years before the payment of the dividend if the dividend is to qualify for the exemption from withholding tax provided by the Directive. One wonders whether this is a rather narrow interpretation of the Directive. One had expected that the uninterrupted period of at least two years could be satisfied if the parent had the requisite holding in the subsidiary at the time of payment of the dividend and it continued to maintain that holding for a period after the payment of a dividend, which, taken together with the period before the payment of dividend, totalled two years. The wording refers to companies which 'do not maintain' rather than 'have not maintained' which is the wording that one would have expected if one was to look at a preceding holding period.

The narrow Dutch interpretation means that in a case where a holding has been switched between two companies within a group for the purposes of some internal reorganisation the transferee company will have to start counting afresh its holding period for qualification for the withholding tax free dividend from the Netherlands. A further point is the position with subscriptions for additional shares in a company: are those shares to be regarded as a separate holding so that they have to be held for two years in order to qualify for the exemption under the directive? The position here seems rather clearer because the requirement for the holding is only in order to qualify the company as a parent company. Once the qualification is satisfied then all dividends paid to that parent company whether on shares acquired more than two years before and forming part of the holding which qualified it as a parent company in the first place, or on additional shares subscribed (or indeed issued by way of bonus issue), should qualify for the exemption under the directive.

It would seem that Member States cannot extend the terms of the directive on the derogation in relation to holdings according to their own interpretation on the basis that it is concerned with the prevention of fraud or abuse, but must observe it strictly. This is the conclusion which seems to follow from the fact that the exclusion of domestic or agreement based provisions as to fraud or abuse is contained in Article 1, as already mentioned. Therefore Article 3 seems to envisage that in looking at the holding period it is not dealing with a case of fraud or abuse but rather with the basic requirements for qualification as a parent company.

The provision in Article 1 that the Directive does not preclude the application of domestic or agreement based provisions required for the prevention of fraud or abuse leaves open the 
need to refer to the precise terms of implementation in each state to see what is the correlation between the domestic anti-avoidance rules and the Directive provisions. (For example, refusal to grant relief at source could be justified on the grounds that it is to prevent fraud or abuse). It is clearly envisaged that the domestic anti-avoidance law can overrule the Directive. This contrasts with the position in relation to tax treaties in many countries where the provisions of the tax treaty will prevail over the provisions of domestic law. In addition to the stance which is taken on the continuation of domestic anti-avoidance rules it will be interesting to see how wide an interpretation is given to the application of agreement based provisions. At first sight this provision is simply intended to allow states which by way of double tax treaties already allow for no withholding tax, or provide for credit or exemption relief on dividends received, to continue to do so and for those treaty provisions not to be over-ridden by the Directive simply because they are themselves subject to provisions concerned with fraud or abuse, such as a test requiring that the recipient should be the beneficial owner or provisions concerned to prevent dividend stripping. However some countries might seek to use it to apply other anti-abuse provisions normally included in their treaties such as anti-treaty shopping tests.

Thus the advent of the dividend Directive, and indeed other Directives in due course, may lead to some unexpected traps for the companies concerned. For the adviser that means additional work in ensuring that as far as possible these are avoided. At the beginning of a new year which sees many economies in recession this new layer of complication is not necessarily, for the adviser, bad news. 